\title{
Venture Capital Best Practice Strategies To Reduce Economic Uncertainty In Biofuel Investing
}

David A. Blum, DBA, Northcentral University, USA

\begin{abstract}
Independent venture capital firms require actionable economic best practice strategies to reduce uncertainty when investing in biofuel firms. Biofuels derived from plant oils are a primary source of renewable fuel energy replacing petrol diesel. Investing in biofuels is fraught with high capital start-up costs and inaccurate portfolio firm valuation models lessening venture capital personnel ability to achieve higher levels of successful biofuel firm exits. The gap in literature addressed in this paper is venture capital best practice strategies to reduce economic uncertainty in biofuel firms investing are an unexplored phenomenon. Reducing and prospering from the effects economic uncertainty requires venture capital firms to implement best practice strategies. This paper provides venture capital firms with best practice strategies to reduce economic uncertainty when in investing in biofuel firms. Utilizing multiples, net present value, internal rate of return, and venture capital model for establishing a valuation price for portfolio firms are actionable economic best practice strategies addressed in this paper. The best practice strategies presented in this paper might reduce economic uncertainty, increase the number of successful exists, and encourage increased funding of biofuel energy firms, contributing to cleaner and healthier communities throughout the United States.
\end{abstract}

Keywords: Biofuel Investing; Independent Venture Capital (IVC); Venture Capital

\section{INTRODUCTION}

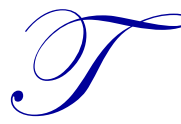

he U.S. economy requires reliable and inexpensive sources of energy to fuel economic growth and to create wealth. Locating reliable, abundant, and sustainable sources of energy is critical to the nation's economic, social, and environmental development (Singh, Nigam, \& Murphy, 2011). One sustainable and reliable source of fuel energy is biofuels.

The use of biofuels is a promising sustainable source of energy to replace petrol diesel while meeting existing and future transportation fuel needs (Bajhaiya, Mandotra, Suseela, Toppo \& Ranade, 2010; Demirbas, 2008; Hossain, Salleh, Boyce, Chowdhury \& Naqiuddin, 2008; Singh et al., 2011). Biofuels are a renewable energy source derived from plant-like sources that can be used for heat and fuel (Brennan \& Owende, 2009). Plant-like sources include jatropha, corn oil, canola, soybean, palm oil, and algae. Biofuels could play an essential role in replacing petroleum as a viable alternative in reducing long-term carbon dioxide emissions (Brennan \& Owende, 2009; Singh et al., 2011).

For biofuel firms to transition from concept to fuel production requires funding in advance of $\$ 10$ million just for capital start-up costs (Gallagher, 2011). Acquiring funding in the millions of dollars requires biofuel firms to partner with independent venture capital firms (IVC). IVCs are the primary source of funding for entrepreneurial oriented biofuel firms (Li \& Zahra, 2012). IVC firms fund high risk, market scalable, and high growth ventures (Olsson, Frydenberg, Jakobsen, \& Jessen, 2010). 
Investing in biofuels is fraught with high capital start-up costs and inaccurate portfolio firm valuation models lessening venture capital personnel ability to achieve higher levels of successful biofuel firm exits. Reducing and prospering from the effects of these uncertainties requires IVC firms to implement best practice strategies. In this paper, I focused on best practice strategies IVCs can use to reduce economic uncertainty in biofuel investing.

\section{LITERATURE REVIEW}

IVC best practice strategies to reduce economic uncertainty in biofuel firms investing is unexplored in the extant peered literature. The literature is replete with strategies to reduce asymmetry of information vis-à-vis portfolio firm by utilizing staging, due diligence, and monitoring portfolio firm performance (Schertler \& Tykvova, 2011; Wiltbank, 2005; Zhang, 2011).

\section{Staging}

Staging is a common practice and an vital activity to reduce uncertainty by limiting negative financial exposure in subsequent staging rounds, reducing the effects of asymmetry of information, and preventing the funding of low return on investment projects (Dahiya \& Ray, 2012; Geronikolaou \& Papachristou, 2011; Hsu, 2010; Smolarski \& Kut, 2011). IVC firms face maximum risk in the staging process during the initial round of financing (Smolarski \& Kut, 2011). By staging, the IVC firm invests capital and provides additional value-added services to the portfolio firm (Smolarski \& Kut, 2011). Wiltbank, Read, Dew, and Sarasvathy (2009) and Dahiya and Ray (2012) indicated that staging mitigates moral hazard by avoiding the introduction of significant portions of funding at the beginning of a project. Hsu found the level of the risk-free interest rate is not a major determinant in the timing of funding at a particular stage. Incremental financing helps the IVC to define goals, monitor the progress of the portfolio firm, and provides the IVC with the option to abandon a project, to delay further investment in a project that is not performing to agreed to standards, or to invest in the opportunity (Driouchi, Leseure, \& Bennett, 2009; Rajan, 2010; Smolarski \& Kut, 2011).

\section{Due Diligence}

During the due diligence process, IVC firms focus on reducing uncertainty (Blum, 2014). Due diligence is measured by the total hours spent performing research on the portfolio company (Wiltbank et al., 2009). Before making a financial investment, the IVC firm performs extensive research on the portfolio firm's product line, management team, and internal and external competitive environments (Lehtonen \& Lahti, 2009; Wiltbank et al., 2009). For example, the IVC might:

- Review background of key management,

- Conduct target market analysis,

- $\quad$ Analyze current and past financial statements,

- $\quad$ Assess competitive advantage and market trends,

- Determine if the portfolio firm has a scalable technology,

- Locate pending legal action,

- $\quad$ Review provisional and approved patents,

- $\quad$ Ensure the portfolio firm product serves an everyday need,

- $\quad$ Research comparables from online venture capital databases to determine valuation price, and

- $\quad$ Evaluate similar portfolio firms in the market before deciding to invest (Blum, 2014).

The time spent by IVCs conducting due diligence is generally proportionate to the anticipated investment funding size (Wiltbank et al., 2009). According to Lehtonen and Lahti (2009), the time from screening to early funding can take approximately 6 months. Yung (2009) countered that the average was closer to 3 months. IVC performing extensive due diligence are more involved in the postinvestment operations of the portfolio firm and experience significantly higher return on investment through a successful exit (Wiltbank et al., 2009). Wiltbank et al. stated IVCs who focused on early funding opportunities experienced few negative exits. 


\section{Monitoring Performance}

IVCs can reduce asymmetry of information by participating in the management and operations of the portfolio firm. IVC firms invest equity capital without a guarantee of a return on investment (Rajan, 2010). The goal of monitoring is to enhance IVC return on investment and add value to portfolio companies (Rajan, 2010). Participation involves monitoring operations by overseeing, analyzing, and critiquing financial performance and defining strategies and markets (Wiltbank, 2008). IVCs add value by sitting on the board. As board members, the IVC works closely with the portfolio firm's management team, acting as a sounding board, and providing strategic advice. Another example would be for the IVC to utilize established business networks to help the portfolio firm obtain new customers, hire key personnel, or to engage with strategic partners (Rajan, 2010). The IVC also adds value during the exit process by helping to locate investment bankers and in successfully presenting the portfolio company to public or private investors (Rajan, 2010).

Possibly the most critical value addition that an IVC can provide to the portfolio firm is enabling an initial public offering (IPO), strategic merger, sale, or acquisition (Rajan, 2010). Large private equity and IVC investors have well-connected networks and possess an in-depth understanding of the capital markets (Rajan, 2010). Therefore, if the portfolio company wants to list as an IPO, acquiring the best merchant banker and the ability to value the portfolio firm correctly is vital to raising the expected funds (Rajan, 2010). The IVCs' goal throughout the entire investment process is to focus on reducing asymmetry of information, contribute knowledge and expertise to the portfolio firm while achieving large financial returns on investments (Rajan, 2010; Wiltbank, 2008).

\section{THE PROBLEM}

Biofuels are an abundant and sustainable source of fuel worldwide. In 2013, the global biofuels market size was 97.8 billion U.S. Dollars (Statista, 2014). Without modification to current systems, biofuels can replace petroleum as a primary fuel source. However, for the IVC, high economic uncertainty exists when investing in biofuels influencing decision-making and inhibiting IVCs from achieving greater levels of successful exists (Li \& Mahoney, 2011). Current best practice strategies focuses on reducing asymmetry of information vis-à-vis portfolio firms and are not sufficient to overcome the economic uncertainty inherent in biofuels investing. This paper provides directors and managing partners at IVC firms actionable best practice strategies to reduce economic uncertainty when investing in biofuel portfolio firms.

\section{BEST PRACTICE STRATEGIES}

A best practice is the most effective, acknowledged, universal, repeatable, and efficient methods recommended by experts that facilitate an organization's achievement and implementation of a goal (Xu \& Yeh, 2012). Alleviating high economic uncertainty requires effective business practice strategies entailing the implementation of business models, quality standards, and product categories that define future market activity (Berglund, 2011). Expected returns models in terms of multiples, net present value, internal rate of return, and the venture capital model are best practice strategies if implemented, permit IVCs to reduce economic uncertainties when in investing in biofuel firms.

\section{Expected Returns Models}

\section{Multiples}

Regardless of the investing stage, IVCs require at least multiples of $3 \mathrm{x}$ meaning three times return on revenue, or $3 \mathrm{x}$ gross margin, or $3 \mathrm{x}$ the net profit at exit. Some later stage IVCs might accept $2 \mathrm{x}$, while most early stage IVCs expect a minimum $3 \mathrm{x}$ on revenue (Blum, 2014). Multiples range from $3 \mathrm{x}$ to 10x is the most appropriate model to reduce uncertainty for most biofuels investing (Blum, 2014). For example, if an IVC invests $\$ 10$ million in Year 1 and the portfolio firms exists in Year 3; the IVC expects to earn approximately \$40 million in gross profit. IVC firms measure portfolio firm revenue while tracking the amount of funds rose from investors (Blum, 2014). Venture capital funds accounts exist for 10 years and IVCs expect a successful exit within 2 to 5 years of initial funding (Blum, 2014). 
Net Present Value (NPV)

NPV is the sum of the present values of a project's cash flows with the present values found by discounting all inflows and outflows at the project's cost of capital. If NPV is zero or higher, the project should be accepted, if the NPV is less than zero, the project should be rejected. Note, a unique discount rate does not exist that will always be suitable for the calculation of NPV for biofuel firms. Different discount rates will be appropriate for different purposes. In specific applications related to biofuels, the correct discount rate to use will often be a specified interest rate or rate of return. Table 1 is the formula for calculating NPV.

Table 1: NPV Formula and Example

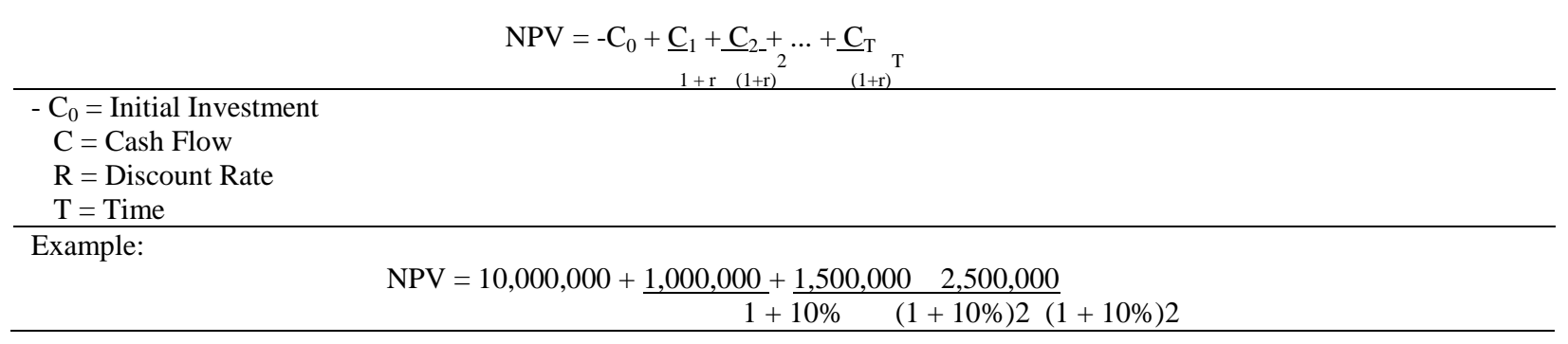

In the example, the initial investment was $\$ 10$ million. The expected cash flow for Year 1 is $\$ 1$ million with a $10 \%$ discount rate. The expected cash flow for Year 2 is $\$ 1.5$ million with a $10 \%$ discount rate. Total cash flow is $\$ 2.5$ million over two years. The NPV for the two-year project is $-\$ 7,438,016.53$. In this scenario, the project should be rejected.

\section{Internal Rate of Return (IRR)}

IRR also known as rate of return is used by IVCs to compare and measure the profitability of an investment by incorporating the time value of money where a project's NPV $=0$ (Blum, 2014). At zero, the project's cash flows are equal to costs. IRR is the discount rate equating the present value of a project's cash inflows to the present value of costs and outflows. Determining the minimum rate of return is known as the hurdle rate. Higher IRR provides the investor with a greater probability of success and a reduction in uncertainty in investing in biofuel firms. IRR reduces the risk of an investment to achieve higher returns on risk adverse alternatives (Blum, 2014). If IRR is greater than the hurdle rate, the IVC should accept the project. If IRR is less than the hurdle rate, the project should be rejected. Table 2 is an IRR estimation based on net income for five years.

Table 2: IRR Estimation based on Net Income

\begin{tabular}{lccc}
\hline & Project 1 & Project 2 & Project 3 \\
\hline Net Investment & $-10,000,000$ & $-15,000,000$ & $-5,000,000$ \\
Year 1 Net Income & $5,000,000$ & 1,000000 & $1,000,000$ \\
Year 2 Net Income & $8,000,000$ & $1,500,000$ & 200,000 \\
Year 3 Net Income & $1,000,000$ & $1,250,000$ & 250,000 \\
Year 4 Net Income & $3,500,000$ & $1,000,050$ & 300,000 \\
Year 5 Net Income & $5,000,000$ & $2,000,000$ & 400,000 \\
\hline IRR & $39 \%$ & $-21 \%$ & $-25 \%$ \\
\hline
\end{tabular}

The IVC should consider accepting Project 1 and reject Projects 2 and 3. The IVC should accept IRR between $36 \%$ and $45 \%$ return on early stage investments and between $26 \%$ and $30 \%$ returns for expansion and later stage exits before considering accepting a biofuels portfolio firm project (Manigart et al., 2002). If the interest rate an investor pays to borrow money is less than the IRR, the project should be accepted. 


\section{Venture Capital Method}

IVCs use the venture capital method to valuate prerevenue portfolio firms with an anticipated exit within seven years. The method is used by IVCs to estimate an exit price. The venture capital method is calculated as:

ROI $=$ Terminal Value $\div$ Post-money Valuation. Then, Post-money Valuation $=$ Terminal Value $\div$ Anticipated ROI

Terminal Value is the anticipated selling price (or investor harvest value) for the biofuel portfolio firm at a future time, generally 3 to 7 years. Table 3 is an example of using the venture capital method.

Table 3: IRR Estimation based on Net Cash Flows

\begin{tabular}{|c|c|c|}
\hline \multicolumn{3}{|c|}{ Discount the Terminal Value to Present Value } \\
\hline Annual Earnings(Projected NI) & $\$ 10,00,000.00$ & (at exit date) \\
\hline In Year & 5 & (at exit date) \\
\hline PE(multiple) & 15 & \\
\hline Required Rate of Return & $25 \%$ & \\
\hline Value of firm & $\$ 49,152,000$ & \\
\hline \multicolumn{3}{|c|}{ Calculate the Required Ownership Percentage } \\
\hline Initial Investment & $\$ 4,500,000.00$ & \\
\hline Equity Stake & $9.16 \%$ & \\
\hline Current Outstanding Shares & $1,000,000$ & (pre) \\
\hline Total Outstanding Shares & $1,100,779$ & (post) \\
\hline VC Owns \# Shares & 100,799 & \\
\hline Share Price & $\$ 44.65$ & \\
\hline Pre-Money Valuation & $\$ 44,652,000$ & \\
\hline Post-Money Valuation & $\$ 49,152,000$ & \\
\hline
\end{tabular}

All investments projects have uncertainty. Implementing expected returns models could reduce economic uncertainty when investing in biofuel firms. While the returns models provide a method to reduce economic uncertainty, all models have limitations. Limitations include all conceivable variables cannot be quantified, too many variables exist to calculate a useful outcome, and multiples comparatives could be scarce. Predicting $3+$ years into the future is challenging in determining the portfolio firm's worth in terms of market value, financial performance, and consumer preferences. For IVCs who choose not to use expected returns models, valuations tend to be ad hoc.

\section{CONCLUSION}

In this paper, I focused on expected returns models best practice strategies. The models results are only as accurate as the input provided by the IVC. Reducing and prospering from the effects of economic uncertainty requires IVC firms to implement economic best practice strategies. With reduced economic uncertainty, IVCs might be more willing to invest greater funds, and provide knowledge and expertise to nascent biofuel firms benefiting the U.S. economy, physical environment, and social responsibility.

\section{AUTHOR INFORMATION}

David Blum is an adjunct faculty mentor in the School of Business Management and Technology at Northcentral University. Dr. Blum holds a Bachelor's Degree in History from Bellarmine University, a Master of Business Administration (MBA) in Sustainable Business from Marylhurst University, and a Doctor of Business Administration (DBA) from Walden University. Email: david@greenwolfconsulting.com

\section{REFERENCES}

1. Bajhaiya, A. K., Mandotra, S. K., Suseela, M. R., Toppo, K., \& Ranade, S. (2010). Algal biodiesel: The next generation biofuel for India. Asian Journal of Experimental Biological Science, 1, 728-739. Retrieved from www.ajebs.com 
2. Berglund, H. (2011). Early stage venture capital investing: comparing California and Scandinavia. Venture Capital, 13, 119-145. doi:10.1080/13691066.2011.558366

3. Blum, D. A. (2014). A venture capital handbook: Best practice strategies for investing in microalgae biodiesel. Huntsville, AL: Emerson Street Press.

4. Brennan, L., \& Owende, P. (2010). Biofuels from microalgae-A review of technologies for production, processing, and extractions of biofuels and co-products. Renewable and Sustainable Energy Reviews, 14, 557577. doi:10.1016/j.rser.2009.10.009

5. Dahiya, S., \& Ray, K. (2012). Staged investments in entrepreneurial financing. Journal of Corporate Finance, 18, 1193-1216. doi:10.1016/j.jcorpfin.2012.07.002

6. Demirbas, A. (2008). Biofuels sources, biofuel policy, biofuel economy and global biofuel projections. Energy Conversion and Management, 49, 2106-2116. doi:10.1016/j.enconman.2008.02.020

7. Driouchi, T., Leseure, M., \& Bennett, D. (2009). A robustness framework for monitoring real options under uncertainty. Omega, 37, 698-710. doi:10.1016/j.omega.2007.09.004

8. Gallagher, B. J. (2011). The economics of producing biodiesel from algae. Renewable Energy, 36, $158-162$. doi:10.1016/j.renene.2010.06.016

9. Geronikolaou, G., \& Papachristou, G. (2011). Is there an adverse effect of uncertainty on Venture Capital? The European evidence. Applied Economics Letters, 18, 383-388.doi:10.1080/13504851003670601

10. Hossain, A. B. M. S., Salleh, A., Boyce, A. N., Chowdhury, P., \& Naqiuddin, M. (2008). Biodiesel fuel production from algae as renewable energy. American Journal of Biochemistry and Biotechnology, 4, $250-254$. doi:10.3844/ajbbsp.2008.250.254

11. Hsu, T.-W. (2010). Staging of venture capital investment: a real options analysis. Small Business Economics, 35 , 265-281. doi:10.1007/s11187-008-9158-2

12. Lehtonen, O., \& Lahti, T. (2009). The role of advisors in the venture capital investment process. Venture Capital an International Journal of Entrepreneurial Finance, 11, 229-254. doi:10.1080/ 13691060902972851

13. Li, Y., \& Mahoney, J. T. (2011). When are venture capital projects initiated? Journal of Business Venturing, 26, 239-254. doi:10.1016/j.jbusvent.2009.08.001

14. Li, Y., \& Zahra, S. A. (2012). Formal institutions, culture, and venture capital activity: A cross-country analysis. Journal of Business Venturing, 27, 95-111. doi:10.1016/j.jbusvent.2010.06.003

15. Manigart, S., De Waele, K., Wright, M., Robbie, K., Desbrieres, P., Sapienza, H. J., Beekman, A. (2002). Determinants of required return in venture capital investments: A five-country study. Journal of Business Venturing, 17, 291-312. doi:10.1016/S0883-9026(00)00067-7

16. Olsson, N. O. E., Frydenberg, S., Jakobsen, E. W., \& Jessen, S. A. (2010). In search of project substance: How do private investors evaluate projects? International Journal of Managing Projects in Business, 3, $257-274$. doi:10.1108/17538371011036572

17. Rajan, A. T. (2010). Venture capital and efficiency of portfolio companies. IIMB Management Review, 22, 186197. doi:10.1016/j.iimb.2010.10.009

18. Schertler, A., \& Tykvova, T. (2011). Venture capital and internationalization International Business Review, 20, 423-439. doi:10.1016/j.ibusrev.2010.07.009

19. Singh, A., Nigam, P. S., \& Murphy, J. D. (2011). Renewable fuels from algae: An answer to debatable land based fuels. Bioresource Technology, 102, 10-16. doi:10.1016/j.biortech.2010.06.032

20. Smolarski, J., \& Kut, C. (2011). The impact of venture capital financing method on SME performance and internationalization. International Entrepreneur and Management Journal, 7, 39-55. doi:10.1007/s11365-0090128-1

21. Statista. (2014). Global biofuels market size from 2005 to 2013 (in billion U.S. dollars). Retrieved from http://www.statista.com/statistics/217179/global-biofuels-market-size/

22. Wiltbank, R., Read, S., Dew, N., \& Sarasvathy, S. D. (2009). Prediction and control under uncertainty: Outcomes in angel investing. Journal of Business Venturing, 24, 116-133. doi:10.1016/j.jbusvent.2007.11.004

23. Wiltbank, R. (2005). Investment practices and outcomes of informal venture investors. Venture Capital: An International Journal of Entrepreneurial Finance, 7, 343- 357. doi:10.1080/13691060500348876

24. Xu, Y., \& Yeh, C.-H. (2012). An integrated approach to evaluation and planning of best practices. Omega, 40, 65-78. doi:10.1016/j.omega.2011.03.007

25. Yung, C. (2009). Entrepreneurial financing and costly due diligence. The Financial Review, 44, $137-149$. doi:10.1111/j.1540-6288.2008.00213.x

26. Zhang, J. (2011). The advantage of experienced start-up founders in venture capital acquisition: Evidence from serial entrepreneurs. Small Business Economic, 36, 187-208. doi:10.1007/s11187-009-9216-4 